\title{
Masculinity, vulnerability and prevention of STD/HIV/AIDS among male adolescents: social representations in a land reform settlement ${ }^{1}$
}

\author{
Camila de Oliveira Arraes ${ }^{2}$ \\ Marinésia Aparecida Prado Palos ${ }^{3}$ \\ Maria Alves Barbosa ${ }^{4}$ \\ Sheila Araujo Teles ${ }^{3}$ \\ Márcia Maria de Souza ${ }^{3}$ \\ Marcos André de Matos ${ }^{5}$
}

Objective: to analyze the relationship of masculinity, vulnerability and prevention of STD / HIV / AIDS among adolescent males of a land reform settlement in central Brazil. Method: a qualitative study using as precepts the strands of social representations with teenagers between 12 to 24 years. Results: three categories emerged - Perception of vulnerability; Gender and vulnerability; and, Prevention and vulnerability to STD / HIV / AIDS. Adolescents felt invulnerable to sexually transmitted diseases anchored in the social representations in favor of the male hegemony. An ignorance about forms of prevention for STD / HIV / AIDS was demonstrated in their statements. It is believed that institutional projects such as the School Health Program and the Men's Health Care Program constitute essential tools to minimize factors of vulnerability in this population, since the school is recognized as a social facility that promotes socialization of experiences and contributes to the construction of the identity of the adolescent. Conclusion: the social representations of masculinity collaborate for the vulnerable behavior of the adolescents for the acquisition of sexually transmitted diseases. One hopes that this study can contribute to the production of knowledge and technical-scientific improvement of the professionals, especially the nurse, in order to discuss issues related to male sexuality of adolescents in the situation of the land reform settlement.

Descriptors: Men's Health; Adolescent; Masculinity; Sexually Transmitted Diseases; Health Vulnerability.

\footnotetext{
${ }^{1}$ Supported by Ministério da Educação - Programa de Extensão Universitária (PROEXT 2013 - MEC/SESu).

${ }^{2}$ RN, Resident, Programa de Residência Multiprofissional em Saúde da Família, Faculdade de Enfermagem, Universidade Federal de Goiás, Goiânia, GO, Brazil.

${ }^{3} \mathrm{PhD}$, Adjunct Professor, Faculdade de Enfermagem, Universidade Federal de Goiás, Goiânia, GO, Brazil.

${ }^{4}$ PhD, Full Professor, Faculdade de Enfermagem, Universidade Federal de Goiás, Goiânia, GO, Brazil.

${ }^{5}$ Doctoral student, Faculdade de Medicina, Universidade Federal de Goiás, Goiânia, GO, Brazil. Assistant Professor, Faculdade de Enfermagem, Universidade Federal de Goiás, Goiânia, GO, Brazil.
}

Corresponding Author: Marcos André de Matos Universidade Federal de Goiás. Faculdade de Enfermagem Rua 227, Quadra 68, S/N Setor Leste Universitário CEP: 74605-080, Goiânia, GO, Brasil E-mail: marcosdeminas@yahoo.com.br
Copyright $\odot 2013$ Revista Latino-Americana de Enfermagem This is an Open Access article distributed under the terms of the Creative Commons Attribution Non-Commercial License (CC BY-NC).

This license lets others distribute, remix, tweak, and build upon your work non-commercially, and although their new works must also acknowledge you and be non-commercial, they don't have to license their derivative works on the same terms. 


\section{Introduction}

Adolescence is marked by great transformations and adaptations in the social environment, emotions and body, especially changes related to the phase and the phenomenon of sexuality. These modifications are inherently an experiential and transitory step for the adult phase ${ }^{(1-2)}$. It is a period that is considered critical, since they are in constant search for their own identity and individual and/or group affirmation, that is, their group of peers. Such changes, characteristics of this phase of the life cycle, mean that adolescents in search of the new, motivated by curiosity and little experience, feel invulnerable to Sexually Transmitted Diseases (STDs), especially among the male population ${ }^{(3)}$.

According to the physiological and psychological transformations, added to the cultural aspects, the adolescent develops his sexuality by means of social constructs $^{(4)}$. Some studies show that male adolescents present vulnerabilities anchored in the beliefs of hegemonic masculine sovereignty, i.e., machismo constructed and sustained by society over the decades ${ }^{(5-7)}$

Currently there is a rising tendency in the prevalence of infection with Human Immunodeficiency Virus (HIV) in the juvenile population. In Brazil, of the total of 608,230 reported cases of Acquired Immunodeficiency Syndrome (AIDS), since 1980, 66,114 were young individuals, representing $11 \%$ of the cases reported in the country since the beginning of the epidemic, and sexual transmission accounted for $68 \%$ of $\operatorname{cases}^{(8)}$

Reporting the discovery of AIDS, there is a major preoccupation with STDs requiring, therefore, the development and implementation of public policies focusing on prevention and intensification of the discussions about issues of gender, sexuality and vulnerability ${ }^{(8-9)}$.Thus, to analyze human behavior has been an arduous task, especially when it comes to vulnerable groups such as adolescents residing in areas of land reform settlements.

Although knowledge of the young men about STDs, even tentatively, has increased, there is an increasing trend in the prevalence of these infections ${ }^{(8,10-12)}$, especially due to the sociocultural aspects. However evaluations about this subject are is still incipient in the adolescent phase with the male population that lives in areas considered to be of great individual, social and programmatic vulnerability, such as settlements.
Historically, economic and sociocultural constructs of this population group collaborate for the understanding of the form in which adolescent settlers attribute meanings to the social representations of human sexuality. Thus, it is believed that understanding how these adolescents construct their masculinity and perception of vulnerability to STD/HIV/AIDS can create subsidies and strengthen the social infrastructure with innovative technologies for the development of interventions. Equally subsidized are the (re)formulation of public health policies constituted so as to receive and make men feel they are an integral part of these policies, aiming to achieve the coveted comprehensive care in the health of men.

Therefore, this current research represents an important advance towards a better understanding of this emerging social group marked by the great geographical mobility, social and historical struggles of precarious housing in different regions, making them vulnerable to infectious diseases, particularly those diseases transmitted sexually(11-12). Thus, the present study aimed to analyze the relationship of masculinity, vulnerability and prevention of STD/HIV/AIDS among adolescent males of a land reform settlement.

\section{Methodology}

This was a descriptive study of a qualitative nature that emerged from the need to understand some uneasiness apprehended from facts and words of the everyday adolescent group. Such material was able to reveal the reality that could not be quantified and deepened into the world of meanings of actions and human relationships, enabling the analysis and valuation of subjectivity. Thus, strands of social research on the social representations were used as precepts(13).

It is further understood that social representations constitute a unique form of shared knowledge in the social group in which the investigation was part of a socially developed category, directed to practical life, allowing subjects orientation before a socially relevant

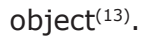

Participants in the research were 11 adolescents of 12-24 years of age, residing in the land reform settlement and who, after knowing the objectives of the study, expressed interest in participating and returned the Terms of Free and Informed Consent Form (TFIC) signed by parents or guardians. According to the Reference Center for Social Assistance in the Region 
(CRAS-GO) the settlement was designed, primarily, to house needy families arising from irregular areas and for environmental preservation. In the settlement, located on the outskirts of the large region of Goiânia-Goiás, there are about 2400 homes, and only three years ago the site had coverage from a single unit of the Family Health Care and one Municipal Education Institution, which did not allow for care to the entire community settlement. There was also no area dedicated to leisure ${ }^{(14)}$.

To determine the age of the social actors in this study, adolescents were considered eligible who lived in the settlement for more than one year and who were aged between 12 and 24 years, as established by the United Nations Organization for Education, Science and Culture $^{(15)}$ and by the Statute of the Child and Adolescent $(\mathrm{ECA})^{(16)}$.

All settled school adolescents were invited to participate in the study, and the selection proceeded by means of convenience sampling with the number of individuals determined by the principle of qualitative research, that occurs with data saturation. We excluded subjects who had a residence time in the settlement less than 12 months, were aged below 12 and above 24 years, and adolescent minors who did not return the consent form signed by their legal guardian. Participants were identified by Subject, plus an Arabic numeral.

Data collection was conducted by a previously developed script consisting of two parts: the first included the socio-demographic characteristics and risk behaviors for STD/HIV/AIDS of respondents. The second contained three questions directed at the issues of sexuality, gender and vulnerability to STD/HIV/AIDS, in order to obtain through their textual productions the social representations of the adolescent settlers.

The interviews were conducted in the month of August of 2012, with a duration of approximately one hour, in the only school in the settlement, and were recorded and transcribed verbatim. It is noteworthy that during the process of data collection there was a concern about the privacy of individuals, because for the male teenager to talk about his own sexuality is still replete with taboos, beliefs and cultural values ${ }^{(3)}$.

To proceed with the analysis of the collections of the narratives of individuals investigated, the thematic modality of Bardin was employed(17), following the steps: pre-analysis; exploration of transcribed words; processing of the data; inferences and interpretations.
We opted for the technique of content analysis to understand that such an analysis is no longer solely a technical procedure to become part of a history, by means of seeking theory and practice in the field of social research(13,17),

Initially, we proceeded with an exhaustive reading of all the material, which permitted us to grasp not only the content, but also the similarities and contradictions of the information, allowing the grouping of responses and the organization of categories according to the objectives and the theoretical axis of the social representations. Finally, interpretation of the data

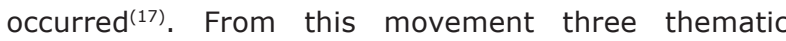
categories emerged: I -perception of vulnerability to STD/HIV/AIDS; II - gender and vulnerability to STD/ HIV/AIDS; and III - prevention and vulnerability to STD/HIV/AIDS.

The study followed the requirements of Resolution 196/96 and was approved under CEP-UFG protocol, No. $365 / 11$. The research activities were initiated after the knowledge of the adolescents of the age of majority and those responsible for the minors, on the nature, objectives, methodology, risks and anticipated benefits of the study.

\section{Results and Discussion}

In relation to the sociodemographic characteristics, $36.4 \%$ and $63.6 \%$ reported being natives of the northern and midwestern region of Brazil, respectively. The family income of the adolescents was 2.5 times the minimum wage, showing that it is a low-income population, specific to populations of settlements.

The mean age was 17 years, with eight years of schooling, the phase in which adolescents, generally, are more exposed to risk behaviors for acquiring sexually transmitted diseases, due to the inherent characteristics of adolescence ${ }^{(5)}$.The mean age of first sexual intercourse reported was 13 years, with an mean of twenty-one sexual partners, data corroborated with a multicenter study with adolescent students in Brazil(1).

On the use of barrier methods during sexual intercourse, $27.3 \%$ and $54.5 \%$ of the adolescents reported never and eventually using condoms, respectively. Whereas $36.4 \%$ reported sexual relations with users of illicit drugs. The use of illicit drugs was reported by $37.0 \%$ of individuals and the use of tobacco by $45.5 \%$, with a mean of 11 cigarettes daily. Already the use of alcohol was reported by $90.0 \%$ 
of adolescent settlers. Concerning the relationship between masculinity, vulnerability and prevention of STD/HIV/AIDS in the reports of adolescent males, it was described in the form of thematic categories.

\section{Perceived vulnerability to STD/HIVIAIDS}

Despite the increasing trend of paradigm changes in relation to dialogue of adolescents with their family and/or friends with whom they more freely express their sexuality, and the extensive information easily available in the media, many adolescents felt invulnerable to sexually transmitted infections, especially in the case of male adolescents. Their words demonstrated: If I have a chance to get disease? [laughs] The way I do I do not think so! Hmmm, I have knowledge and also I did not have sex with anyone! (Subject 7). No! Because I avoid by using a condom [...] only! And then, when we know the person, right, for three months, depending of the person, you don't need to use it. [...] (Subject 11).

In fact, several studies show the representations that adolescent have to feel invulnerable to STD/HIV/ $\operatorname{AIDS}^{(3,18)}$. This finding is consistent with the alarming epidemiological data about high morbidity-mortality and resistance of the male population in Brazil, seeking health services because of the disease and the search for primary care have been considered a sign of male weakness and contributes so that men, in all life cycles, are deemed invulnerable ${ }^{(19-20)}$.

Therefore, it is believed that the discussion about the National Policy of Comprehensive Healthcare for Men's Health (PNAISH), combined with behaviorallybased research, is needed in order to promote the improvement of health conditions of the male population of the country. The reduction of morbiditymortality by addressing the risk behaviors and easier access for young people to health services through educational technologies, such as health education, to receive information and or preventive methods, constitute strategies for prevention in the young population ${ }^{(21)}$.

The perception of invulnerability arising from the experience of sexuality of adolescents would require a redefinition of the notion of vulnerability and of the peculiar characteristics of the individual settlers by the health professional, because it is a social group, living in an area of great social vulnerability ${ }^{(9)}$, inherent to the situation of peripheral settlement of a metropolis.

\section{Gender and vulnerability to STD/HIVIAIDS}

Gender issues are central to the understanding of power relations in society, including sexuality and, consequently, vulnerability to STD/HIV/AIDS. It is known that social gender roles are learned from childhood and consolidated throughout life, especially during adolescence, when the individual seeks to establish his identity and plan more specifically for his future ${ }^{(2)}$. The culturally constructed roles of men and women define the behaviors of both genders. This behavior, regarding sexuality, imposes on the woman the lack of ownership of her own body and dominion over sexuality, being incumbent on the man, considered the stronger sex, as his property. In this way, the gendered roles, atributed to men the enjoyment of an unrepressed sexuality, with wide variability of partners and active sexual relationships. The narrative below summarizes precisely the representation of male hegemony, said earlier: We don't think, only after [...] man thinks with his lower head! (Subject 5).

In fact, some adolescents showed that they considered themselves vulnerable, but the vulnerability was directed to the behaviors of their sexual partners. The words of our subjects implicitly illustrated this statement: All the world has it, right! Who knows, man! Disease does not choose, right! Sometimes in a moment of silliness you have a chance to get a dirty woman who doesn't use a condom. (Subject 4). Ah! I think so. Because I'm getting every girl that appears. I am. Uhhh [...] I think it is! [pause] Woman who does it with anyone. (Subject 1) [...] this kind of woman does not care about anything! [...] (laughs) the man doesn't care. They don't mind, right? [...] they only want to be able to finish the job (Subject 11).

Faced with this phenomenon, coordinated work between the actors of health, education and social welfare that privileges the role of male adolescents in actions aimed at promoting sexual health, gender and STD/HIV/AIDS are necessary. The representations raised here can be employed not only in the planning of nursing care, but also in the construction and (re) formulation of public health policies organized in order to accommodate and contribute to the empowerment and co-responsibility of adolescent settlers for self-care of the male population.

Even with feminist struggles around the gender issue, it was observed that the hegemonic masculine sovereignty in human sexuality permeates the thoughts of the adolescents interviewed, especially by delegating the woman's concern with preventive measures for not 
acquiring sexually transmitted diseases, as shown by the following statements: The girl. Ahhh because last week the girls were on the stairs with the kid and over them, in the ladder there! The thing began, here, inside the school. Then, they went [...] Then, there was one woman with three men (Subject 1). Women [...] I think it's much easier for them to get street diseases because she goes too much, she fucks too [...] (Subject 10).

The adolescents' statements confirm the findings of the National Survey of School Health (PeNSE) conducted in 26 Brazilian state capitals and the Federal District, which aimed to describe situations related to sexual health of Brazilians adolescents. It identifyed that the female adolescents had higher awareness about the use of barrier method, and that males had a higher resistence to adherence ${ }^{(1)}$. These results demonstrated the necessity of public sector investments towards works of raising awareness, social co-responsibility of both sexes and negotiating the use of condoms, representing cultural issues to be met.

In recent decades, both in Brazil and in other countries, many researchers, nongovernmental organizations (NGOs), and health/education professionals have been researching about gender and its significance in the socialization of men. This interest has developed into a quest to uncover the social construction of masculinity that affects the sexual health of adolescent males ${ }^{(1,22)}$. This social movement, even incipiently, seems to have shown its first results. The testimonials exemplified: The man has more risk than the woman. I do not know how to answer! But [...] he does! Maybe they don't have information and responsibility $[. .$.$] (Subject 8$ ). Ehhh $I$ think that both are at risk of having STDs, no? For me it's both, both the man and the woman. Ahh , man, I do not know the right answer (Subject 9).

It was evident that the insertion of adolescents into services of health/education through approaches about gender and vulnerability to STD/HIV/AIDS was the major challenge remaining, so that the indicators of promoting men's health are improved. The few attempts to sensitize them through campaigns still have not seemed to have achieved the desired effects. However, somehow, adolescent settlers were receptive to discussions about the subject, which is extremely positive to break the chain of sexually transmitted pathogens transmission in order to promote sexual and reproductive health of this population.

\section{Prevention and vulnerability to STD/HIVIAIDS}

Some studies have observed that the use of barrier methods do not, necessarily, have a direct relationship with the level of knowledge, or that is, with the education of adolescents ${ }^{(1,6)}$. However a major study showed that to have positive results in relation to prevention efficacy of sexually transmitted diseases and/or possible pregnancy, the adolescent must associate the correct information about how to use and access barrier methods, especially condoms $^{(19)}$. The following statements show that the adolescent settler does not use condoms in his sexual practices, grounded in misrepresentation that condoms impairs the sexual pleasure. Ah [...] [pause] I do not use a condom! It is better without condoms [...] gives more pleasure (Subject 5). It is to prevent with a condom! I use it occasionally [...] It's bad! (Subject 2). What? Ah! prevention is to use the things that you have to wear [...] [laughs] Haaa [...] I dont't know [...] I do not use (Subject 10).

The following statements of other respondents denoted that after a few months with a regular partner, generally, the adolescent abandoned condom use. I protect myself using condoms. And, then, when I know the person [...] after some three months, it's not necessary to use them! (Subject 11). Hmmm. Oh, I use a condom. Always. The first two times with the girl and after that no! Ah, she takes medicine (Subject 1).

Some authors have demonstrated that adolescentes, in the beginning of a sexual relationship, have the habit of adhering to condom use, but, in the course of the relationship, usually after three months, stop using it because of misguided beliefs of decreased vulnerability ${ }^{(1-4)}$. With a relationship marked by passion, the partner confidence increases, having unprotected sex becomes a constant due to the emotional involvement and intimacy of the couple, changing to the use of other contraceptive methods, such as a hormonal method (contraceptive pill) ${ }^{(7)}$. On the other hand, the study by the research PENSE(21) also showed that the young, though most frequently using condoms in early relationship, already in recent years, even timidly, had a trend of adherence to condoms for both protection and contraception $^{(1)}$.

Still, one of the adolescents demonstrated concern about STD/HIV/AIDS, involving the representation of the practice of sexual intercourse with someone of the same sex as risky behavior. However, as noted in the following quote the adolescent had the perception that the risk is oriented to homosexuality and not to the lack of adherence to condom use 
during sex. If I am vulnerable? Kind a hard question [...] [laughs] I do not know if I protect myself very well! I do sex with another man [...] eeeee. I guess I'm at risk! [risks] (Subject 9).

In fact, some studies has indicate that homosexuality is configured as risk behavior for STD/HIV/AIDS, due to the characteristics of their own sexual practice ${ }^{(8,23)}$. However, if the individual adheres to preventive measures, such as the systematic use of condoms, the vulnerability is similar to heterosexual intercourse.

The social representations identified in this category showed two relevant points for prevention, considering that this social group resided in an area of great individual, social and programmatic vulnerability: the first point concerned the urgent need to broaden the discussion about models of femininity and masculinity culturally constructed in the settlement, seeking to demystify them. The second issue, envisaged the preparation and execution of intervention strategies directed to men's health, so they can encompass the diversity of Brazilian male population and have applicability to the Unified Health System. It was believed that the implementation of School Health Program (PSE) - Ministry of Education/ Health/UNICEF/UNESCO was an indispensable tool for discussing such issues, since the school represented an important social collaborator in the construction of adolescent identity.

Gender, sexuality and men's health themes should be discussed more in class in a cross-sectional way, especially with the participation of youth leadership. In reality what has happened is that most teachers still teach content related to issues of relationships of human sexuality only from the biological sciences discipline perspective $^{(21,24)}$. It is understood that professors can contribute to the sexuality discussion in various areas of knowledge, since they play mediator roles in the teaching-learning process and opinion formation within educational institutions.

Thus, it is essential that both the adolescent and all those involved in their monitoring, in particular health and education professionals, deeply know and practice the laws relating to sexual and reproductive rights in adolescence and, above all, that health education is a tool that goes beyond the school walls, covering all existing social facilities in the settlement, such as religious and educational institutions, INCRA, neighborhood associations, social service organizations, higher educational institutions, among others. Considering that these rights aim to guarantee the experience of sexuality in a more oriented, safe, healthy way that is free from pre-established concepts for moral, religious, social and cultural patterns ${ }^{(10,25)}$.

\section{Final Considerations}

The male population, for many years, has not received due attention in the priorities of public health policies. Currently, due to male vulnerabilities, many discussions are taking place about the need to support men's health, a fact corroborated by the development of PNAISH in Brazil. However, this program is still in the implementation phase, and some segments of the population, such as adolescents settlers, remain poorly benefited from the policy due to the special characteristics of the Brazilian settlements.

In this context, initiatives in several areas of knowledge are trying to include in their work a greater understanding of the needs of male adolescents, particularly, those relating to human sexuality, as vulnerability, gender and preventive measures for diseases transmitted through sexual contact.

The results arising from the social representations encountered in this study point to the need for effective interventions for sexual education to guide adolescent settlers, since they perceived themselves as invulnerable to infections transmitted by sexual contact, and maintained hegemonic concepts of masculinity and demonstrated in their statements an ignorance about ways to prevent STD/HIV/AIDS.

In this manner, the educational institution of the settlement, along with other existing social agencies, configured favorable spaces for the realization of educational programs aimed at the promotion of sexual and reproductive health of adolescent settlers. These strategies must occur through the work of health education with the adolescent public and continuing education, in order to equip health and education professionals for the implementation of Health and Prevention in the School (SPE) of the PSE.

These interventions should be linked to adolescent social networks (family, friends, teachers, parents), safeguarding the differences in the needs of male adolescents, based on equity, comprehensiveness and humanization, free of preconceived ideas, advocated by PNAISH. In this sense the school, while an educational facility that is supportive of other levels of education, also features a social role to meet the demands of society, especially when issues related to behavioral phenomena require a higher degree of scientific character and varied technologies for teaching-learning 
that meet the specificities and particularities of the target audience.

Finally, it is believed that the nurse, as educator can holistically contribute to the empowerment of adolescents in the idealization/implementation of preventive measures and, consequently, the effective actions that enable the reduction of the vulnerability of these individuals to STD/HIV/AIDS. It is expected that this study contributes to the production of knowledge that will provide information for the technical-scientific improvement of professionals in order to discuss issues related to male sexuality of the adolescent settlers.

\section{References}

1. Malta DC, Silva MAL, Mello FCM, Monteiro RA, Porto DJ, Sardilha LMV. et al. Saúde sexual dos adolescentes segundo a Pesquisa Nacional de Saúde dos Escolares. Rev Bras Epidemiol. 2011;14(1):147-56.

2. Halpern CT. Reframing Research on Adolescent Sexuality: Healthy Sexual Development as Part of the Life Course. Perspect Sexual Reproduct. Health. 2010;42(1):6-7.

3. Greig A, Peacock D, Jewkes R, Msimang S. Gender and AIDS: time to act. Aids. 2008;22 Suppl 2:35-43.

4. Brêtas JRS, Ohara CVS, Jardim DP, Junior WA, Oliveira JR. Aspectos da sexualidade na adolescência. Ciênc Saúde Coletiva. 2011;16(7):3221-8.

5. Liu H, Li S, Feldman MW. Forced bachelos, migration and HIV transmission risk in the context of China's gendeer imbalance: A meta-analysis. AIDS Care: 2012;24(12):1487-95.

6. Dias FLA, Silva KL, Vieira NFC, Pinheiro PNC, Maia CC. Riscos e vulnerabilidades relacionados à sexualidade na adolescência. Rev Enferm UERJ. 2010;18(3):456-61.

7. Marques JS Junior, Gomes R, Nascimento EF. Masculinidade hegemônica, vulnerabilidade e prevenção ao HIV/AIDS. Ciênc Saúde Coletiva. 2012; 17(2):511-20.

8. Ministério da Saúde (BR). Boletim Epidemiológico Aids e DST. Brasília (DF): Ministério da Saúde. Secretaria de Vigilância em Saúde/Departamento de DST, Aids e Hepatites Virais; 2011. 162 p. 8(1).

9. Allotey P, Verghis S, Castillo FA, Reidpath DD. Vulnerability, equity and universal coverage - a concept note. BMC Public Health. 2012;12(1):1-3.

10. Lisa M. Edwards LM, Fehring RJ, Jarrett KM, Haglund KA. The Influence of Religiosity, Gender, and Language Preference Acculturation on Sexual Activity
Among Latino/a Adolescents. Hispanic J Behav Scienc. Nov 2008;30(4):447-62.

11. Coelho RFS, Souto TG, Soares LR, Lacerda LCM. Conhecimentos e Crenças sobre Doenças Sexualmente Transmissíveis e Hiv/Aids entre Adolescentes e Jovens de Escolas Públicas Estaduais da Região Oeste de Goiânia. Rev Patol Trop. 2011;40(1):10-9.

12. Haritha S. The Sex Generation: The impact of teen attitudes, views, and knowledge of contraceptives and sexual activity on the teen pregnancy and STD rates in the United States. Union College. 2011;10(2):12-8.

13. Moscovici S. Representações sociais: investigações em psicologia social. $6^{a}$ ed. Rio de Janeiro: Vozes; 2009. 404 p.

14. Vieira T. Residencial Jardim cerrado tem todas suas mais de 2.300 casas ocupadas. falta nome do jornal, Goiânia 2012, 6 mar; Edição no 001, A:17, col 001.

15. Unesco. Políticas públicas de/para/com juventudes. Brasília: UNESCO; 2004. 304 p.

16. Lei n. 8069 de 13 de julho de 1990 (BR). Estatuto dos Direitos da Criança e Adolescente. Diário Oficial da União [Internet]. 1990. [acesso 30 out 2012]. Disponível em: www.planalto.gov.br/ccivil_03/Leis/L8069.html.

17. Bardin L. Análise de conteúdo. $6^{a}$ ed. Lisboa: Edições 70; 2011. 229 p.

18. Wang B, Bonita S, Xinguang C, Xiaoming L, DinajKoci V, Brathwaite $N$, et al. Predictors of Responsiveness Among Early Adolescents to a School-Based Risk Reduction Intervention Over 3 Years. AIDS Behav. 2012;16(2):469-79.

19. Camargo BV, Campos PHF, Torres TL, Stuhler GD, Matão MEL. Representações sociais de saúde e cuidado: um estudo multicêntrico sobre vulnerabilidade masculina. Temas Psicol. 2011;19(1):179-92.

20. Duarte SJH, Souza RS. A Política Saúde do Homem e sua operacionalização na Atenção Primária à Saúde. Rev Eletr Gestão Saúde. [Internet]. 2012[acesso 13 jan 2013];3(1):520-30. Disponível em: http:// www.gestaoesaude.unb.br/index.php/gestaoesaude/ article/view/140

21. Penna G. Pesquisa Nacional de Saúde do Escolar (PeNSE). Ciênc Saúde Coletiva. 2010;15 suppl 2:3006.

22. McCormack M. Queer Masculinities, Gender Conformity, and the Secondary School. In: In: Landreau JC, Rodriguez JN. Queer Masculinities Explorations of Educational Purpose. New York: Springer Business; 2012. p. 35-46.

23. Hall HI, Walker F, Shah D, Belle E. Trends in HIV Diagnoses and Testing Among U.S. Adolescents and Young Adults. AIDS Behav. 2012;16(1):36-43. 
24. Barros SC, Ribeiro PRC. Educação para a sexualidade: uma questão transversal ou disciplinar no currículo escolar? Rev Electr Enseñanza Ciencias. 2012;11(1):164-87.

25. Moraes SP, Vitalle MSS. Sexual and reproductive rights in adolescence. Rev Assoc Med Bras. 2012; 58(1):48-52. 